\title{
Audiological profile of professional disc jockeys
}

Centro Universitário Planalto do Distrito Federal - UNIPLAN, Faculdade de Fonoaudiologia, Brasilia, Distrito Federal, Brasil.

Conflict of interests: Nonexistent

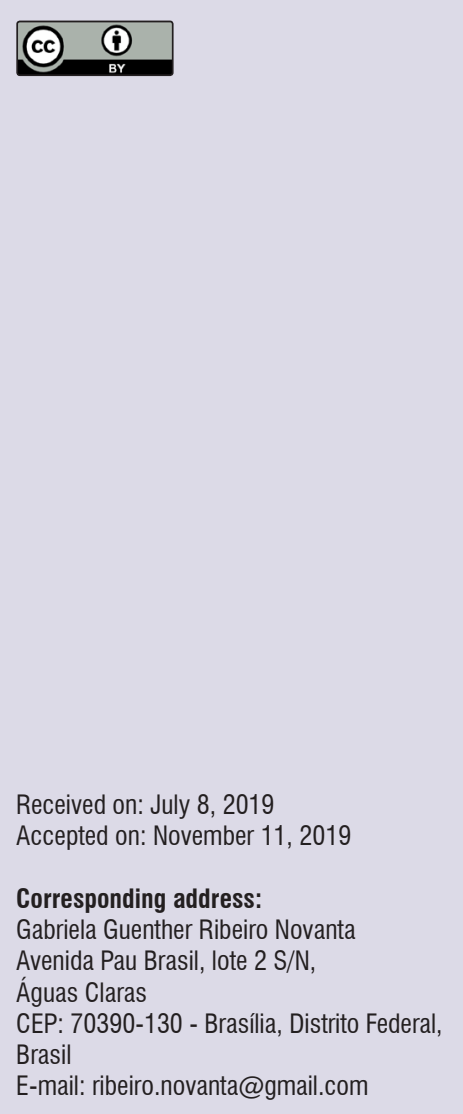

Roseany Alves da Costa ${ }^{1}$ https://orcid.org/0000-0003-3562-7922

Dannyelly Torres Araújo ${ }^{1}$ https://orcid.org/0000-0003-0360-0194

Darlene Cardoso de Souza1

https://orcid.org/0000-0002-7054-173X

Gabriela Guenther Ribeiro Novanta ${ }^{1}$

https://orcid.org/0000-0003-4494-3353

\section{ABSTRACT}

Purpose: to describe the audiological profile of professional disc jockeys acting in cities of the Brazilian Federal District.

Methods: audiometry, tympanometry, transient evoked emissions, and distortion product evoked emissions exams were conducted, as well as interviews, in order to identify auditory symptoms. Appropriate statistical tests were applied, adopting a significance level lower than 0.05 .

Results: a total of 21 disc jockeys, aged between 20 and 45 years, were evaluated. The most cited auditory complaints were feeling of ear fullness (86\%) and tinnitus $(57 \%)$. Auditory thresholds remained predominantly within normal range $(90 \%)$, but thresholds were increased in frequencies from $3 \mathrm{KHz}$ to $6 \mathrm{KHz}$ (38\%). Only $42 \%$ of the sample presented a pass response in transient evoked emissions, and $81 \%$ in distortion product evoked emissions, in both ears.

Conclusion: the research identified auditory thresholds predominantly within standards of normality, though with increased high frequencies, that may be associated with noise exposure. The otoacoustic emissions presented alterations both in the transient ones and in the distortion product.

Keywords: Hearing; Noise-Induced Hearing Loss; Occupational Noise 


\section{INTRODUCTION}

Over the last years, a greater concern regarding the effects of loud noise and music has been observed in society at large. It may be justified by the increase in the levels of noise people have come to be daily exposed to, as a consequence of ever-growing scientific and technological development in the modern world. Its resulting negative effects vary, especially in regard to the degree and frequency of exposure, sound pressure level, and duration of the stimulus ${ }^{1}$.

From the 1960s, the evolution of electronics and the consequent increase of power of the amplifiers attached to the modern musical instruments - led the intensity of music, and thus the risk of hearing loss among musicians, to be enhanced ${ }^{2}$.

The amplified electronic music is an integral part in the schedule of many events, including nightclubs, where the disc jockey (DJ) appears as a protagonist. Concerning auditory health, this professional has been vulnerable to developing auditory alterations due to the frequent exposure to high sound pressure levels. Another aggravating factor is the resistance on the part of some musicians to the use of hearing protection devices ${ }^{3-5}$.

Few studies focus on the possibility of auditory alterations in musicians and DJs who in their occupation, be it professionally or as a hobby, are exposed to high sound intensity ${ }^{1}$, and are often exposed to levels higher than $85 \mathrm{~dB}^{6}$.

From the occupational standpoint, audiometry is the only instrument used as epidemiologic surveillance against hearing loss in noise-exposed workers. However, other tests, such as tympanometry and otoacoustic emissions, may be applied in research on auditory alterations even in subjects with audiometric thresholds within standards of normality?

The use of transient evoked otoacoustic emissions (TEOAE) in early diagnosis of noise-induced hearing loss (NIHL) can be very effective, as it detects temporary changes in the threshold when exposed to high sound pressure 8,9 .

Alterations in amplitude of the distortion product otoacoustic emissions (DPOAE) may precede more serious audiometric alterations, in which case an examination is recommended to diagnose progressive hearing loss in order to implement occupational hearing loss prevention programs ${ }^{8-10}$.

It is important to point out that music professionals have no legal protection in terms of occupational health and safety. The lack of regulation for this profession leads to omissions in establishing health-insuring criteria for these workers, such as defining the length of the workday, requiring the use of personal protective equipment (PPE), and scheduling periodic exams to verify auditory health ${ }^{11}$. This situation may give the erroneous idea that being a musician is not being a worker, or that, if the music is enjoyable, there are no risks for health.

This study aimed at describing the audiological profile of DJs in the cities of the Federal District of Brazil.

\section{METHODS}

This is an observational cross-sectional study, approved by the Research Ethics Committee of the Centro Universitário do Distrito Federal - UDF, Brazil, under evaluation report no. 2.749.134.

The subjects of this study were professional DJs from satellite cities of the Federal District - FD. The audiometry, acoustic immittance, and evoked emissions exams were conducted in a speech-language-hearing teaching clinic at the institution of origin.

The inclusion criteria for participating in the research were: agreeing to participate in the research through the Informed Consent Form (ICF); undergoing audiometry, tympanometry and otoacoustic emissions exams; being a DJ for at least one year; being in the age range from 20 to 45 years; and presenting type $A$ curve on the results of the tympanometry.

The exclusion criteria were: subject outside the abovementioned age range; hearing altered by outer ear problems (presence of cerumen); reporting history of hearing loss prior to beginning the profession; Type As, Ad, C or B curve resulting from the tympanometry exam; and, performing any other noise-exposed professional activity.

On the day scheduled for collecting data, the Informed Consent Form (ICF) and a questionnaire on the workers' auditory health were handed to the subjects. The information pertaining to the procedures to be conducted were also furnished, such as instructions on positioning, and reassurance of its quick and painless character.

After that, the external acoustic meatus was inspected in order to visualize the possible presence of cerumen and other agents which could interfere with the examining procedures.

With these considerations having been established, the participants were submitted to pure-tone threshold audiometry - PTA (Midimate brand audiometer, 622 model), speech audiometry and tympanometry on both 
ears (acoustic-immittance meter, AZ7 model). Lastly, the transient evoked otoacoustic emission (TEOAE) and the distortion product otoacoustic emissions (DPOAE) exams were conducted, with an Interacoustics brand portable device, Oto Read Screening model. The complete assessment took approximately 40 minutes.

After the procedures had been finished, the professionals received the results of the assessments, and adequate guidelines regarding the data were furnished. Those who presented alterations on the exams were referred for an otorhinolaryngologist.

\section{Criteria for the analysis of the results}

The classification described in the Pure-Tone Audiometry, Speech Audiometry, and Acoustic Immittance Measures Procedures Manual from the Sistema de Conselhos Federal e Regionais de Fonoaudiologia (Federal and Regional SpeechLanguage-Hearing Councils System) $(2013)^{12}$, was used for the analysis of the audiometry.

For the TEOAE test, the results obtained with amplitude values equal or superior to -12 , and signalto-noise ratio equal or superior to $3 \mathrm{~dB}$ in five out of six frequencies tested $(1.5 \mathrm{KHz}, 2 \mathrm{KHz}, 2.5 \mathrm{KHz}, 3$ $\mathrm{KHz}, 3.5 \mathrm{KHz}$ and $4 \mathrm{KHz}$ ) were considered normal and/ or "PASS". For the DPOAE, the results considered as normal and/or pass were the ones which obtained amplitude equal or superior to $-5 \mathrm{~dB}$, and signal-tonoise ratio equal or superior to $6 \mathrm{~dB}$ in at least three out of the four frequencies tested $(2 \mathrm{KHz}, 3 \mathrm{KHz}, 4 \mathrm{KHz}$ and $5 \mathrm{KHz})$. The results that presented inferior data based on the abovementioned parameters in at least two frequencies were considered altered (with impairment of the external hair cells of the Organ of Corti). The criteria used were developed based on previous studies $^{13,14}$.

In the statistical analysis, the variables were submitted to the following statistical tests: Pearson's chi-squared test and Fisher's test. For analyses with variables in categorical $X$ and quantitative $Y$, the ANOVA analysis was used. The level of confidence adopted was of $5 \%(p<0.05)$.

\section{RESULTS}

A total of 21 male DJs participated in this study, aged form 20 to 45 years, mean age of 32.1 years (SD \pm 7.30 ).

Regarding musical practice, the time of activity ranged from two to 27 years, mean of 12.6 years (SD \pm 7.79 ). Of these professionals, $33 \%$ have between two and six years of practice; $24 \%$, between seven and 12 years; 29\%, between 13 and 20 years; and $14 \%$ over 20 years.

The average of weekly noise exposure time obtained was of 14.3 hours (SD \pm 11.96 ). The minimum time was of three hours, and the maximum, 56 hours a week. Approximately $40 \%$ answered that they worked from 3 to 6 hours a week.

The auditory symptoms most reported by the professionals were ear fullness $(86 \%)$, tinnitus $(57 \%)$, and discomfort when exposed to high intensity sounds (48\%), as shown in Figure 1. 


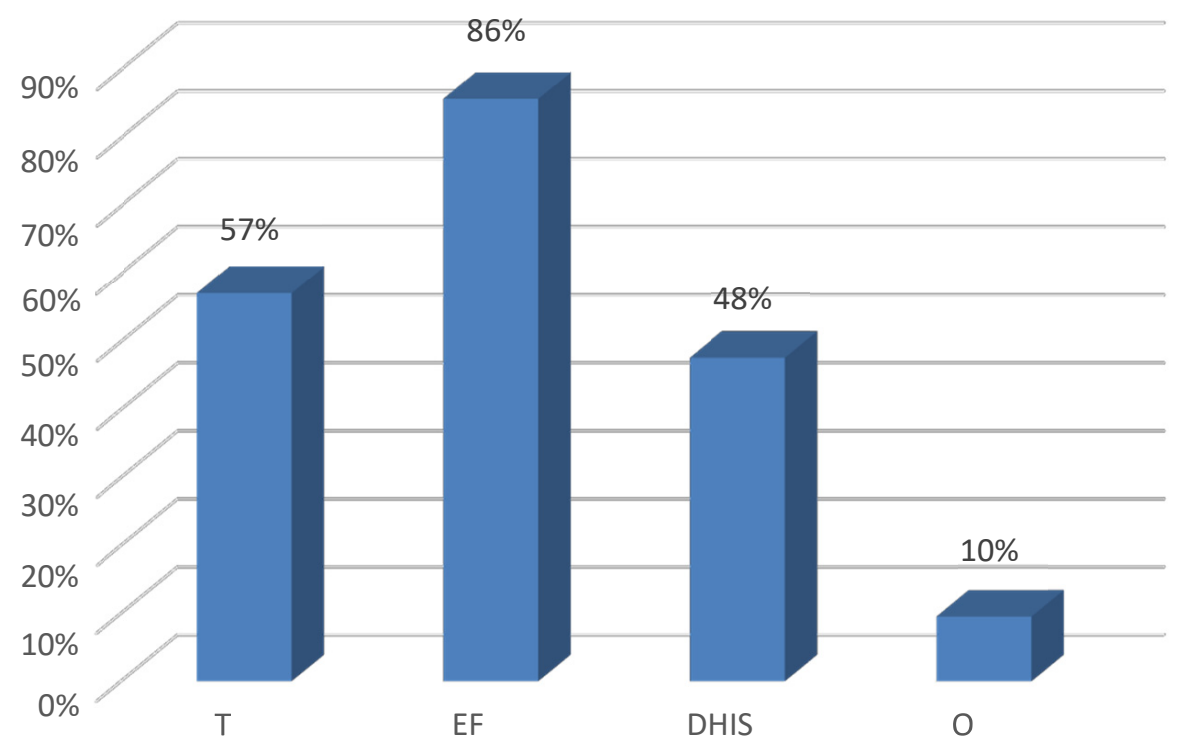

Legend: $\mathrm{T}=$ Tinnitus; EF = Ear Fullness; DHIS = Discomfort with High-Intensity Sounds; 0 = Otalgia

Figure 1. Distribution of auditory complaints found in the group studied

Concerning the thresholds obtained on the pure-tone threshold audiometry, $90 \%(\mathrm{~N}=19)$ of the subjects were found to have audiometry within normal range (all thresholds equal or inferior to $25 \mathrm{~dB} \mathrm{HL}$ ), and $10 \%(\mathrm{~N}=2)$ presented alteration in the auditory threshold in the 3 to $6 \mathrm{KHz}$ frequency range.
In Figure 2, the averages of the airway audiometric thresholds are described. It is possible to observe that the curve demonstrates an increase in thresholds in the frequencies of $3,000,4,000$ and $6,000 \mathrm{~Hz}$, even with auditory threshold predominantly normal.
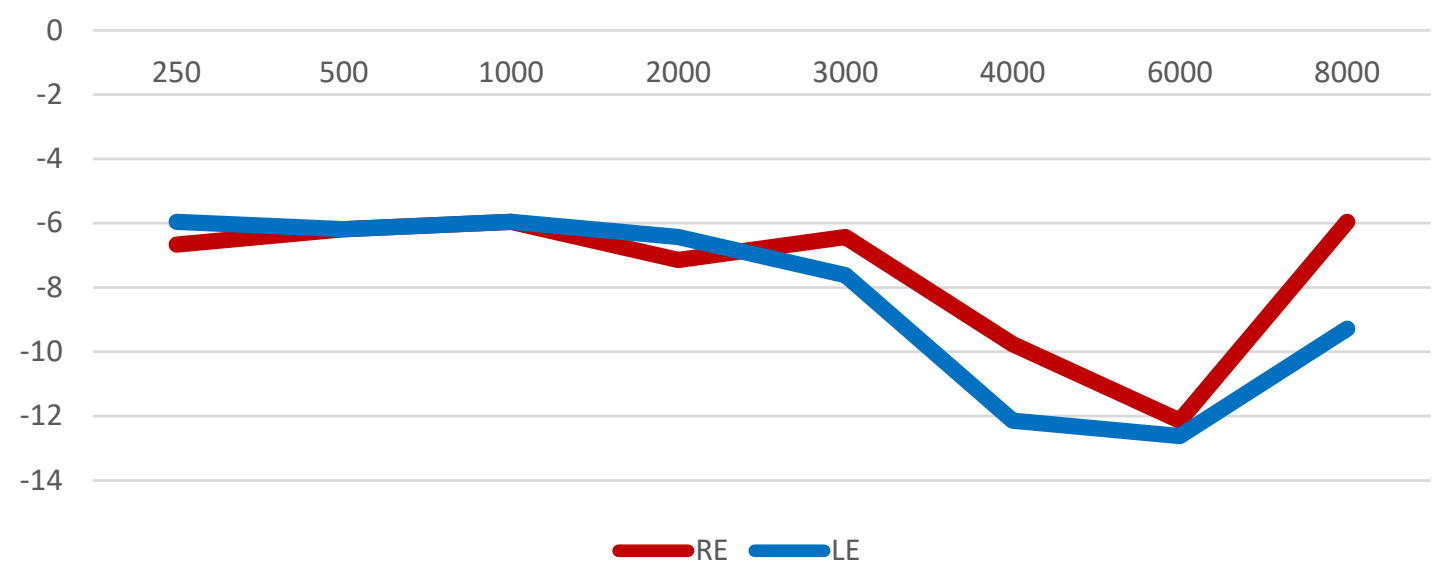

Legend: RE (right ear); LE (left ear).

Figure 2. Average of auditory thresholds distributed by frequency of right ear and left ear 
The overall average of the sample for the frequencies of $500 \mathrm{~Hz}, 1,000 \mathrm{~Hz}$ and $2,000 \mathrm{~Hz}$ was of approximately $6 \mathrm{~dB}$ on both ears, and the average for the frequencies of $3,000 \mathrm{~Hz}, 4,000 \mathrm{~Hz}$ and $6,000 \mathrm{~Hz}$ was of $9 \mathrm{~dB}$ for the right ear and $10 \mathrm{~dB}$ for the left one (Figure 3 ).

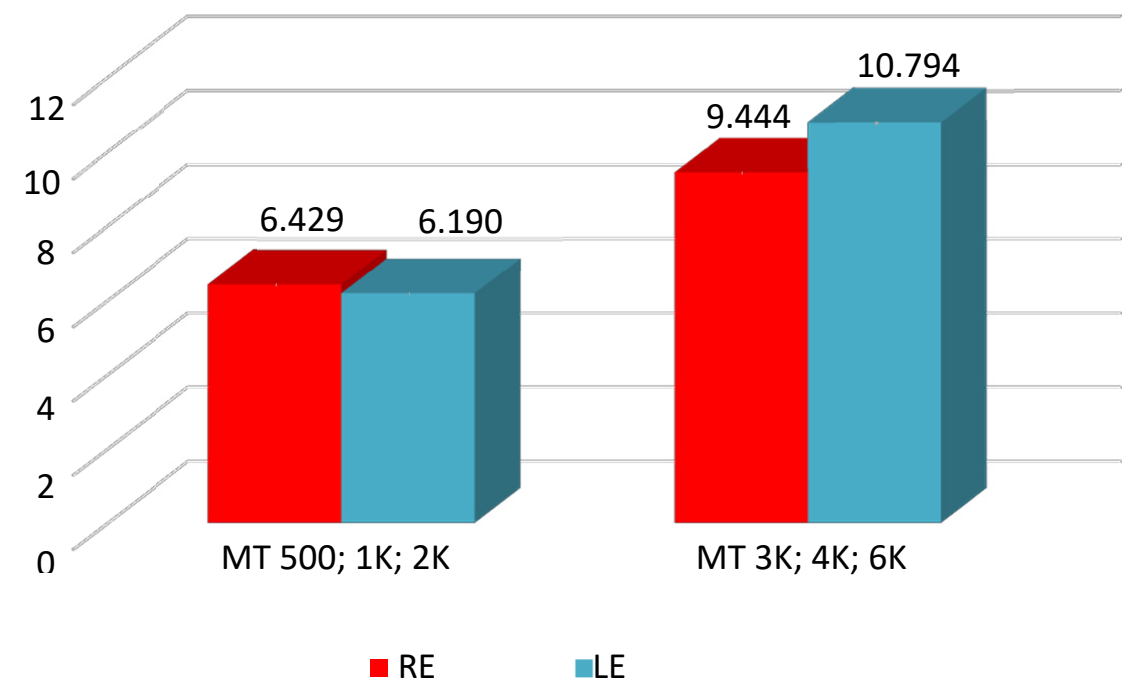

Legend: $\mathrm{TA}=$ three-tone average; $\mathrm{RE}=$ right ear; $\mathrm{LE}=$ left ear

Figure 3. Three-tone averages of $500,1,000$ and $2,000 \mathrm{~Hz}$ in comparison with the averages of $3,000,4,000$ and $6,000 \mathrm{~Hz}$

There was no statistically significant difference when period in professional activity was compared to airway auditory thresholds in the frequencies of $6,000 \mathrm{~Hz}$ on the right $(p=0.5)$ and/or left $(p=0.9)$.
In the analysis of the TEOAE results in relation to the pass/fail criteria, it has been observed that $42.9 \%$ (9) of the participants passed on both ears (Table 1).

Table 1. Occurrence of alterations of transient evoked otoacoustic emissions according to the test results and laterality

\begin{tabular}{|c|c|c|c|c|c|c|}
\hline \multicolumn{7}{|c|}{ Prevalence of alterations of the TEOAE } \\
\hline & \multicolumn{2}{|c|}{ Right Ear } & \multicolumn{2}{|c|}{ Left Ear } & \multicolumn{2}{|c|}{ Both Ears } \\
\hline Result & $\mathbf{N}$ & $\%$ & $\mathbf{N}$ & $\%$ & $\mathbf{N}$ & $\%$ \\
\hline Pass & 12 & 57.1 & 10 & 47.6 & 9 & 42.9 \\
\hline Fail & 9 & 42.9 & 11 & 52.4 & 10 & 47.6 \\
\hline Total & 21 & 100 & 21 & 100 & - & - \\
\hline
\end{tabular}

Legend: $\mathrm{N}=$ number; $\%$ = percentage; TEOAE = transient evoked otoacoustic emissions.

The participants were divided into three groups, according to the thresholds presented on the air-conduction audiometry, namely: from 0 to $15 \mathrm{~dB}$; 20 and $25 \mathrm{~dB}$; and thresholds superior to $25 \mathrm{~dB}$ (right and left ear). As the chi-squared test was applied (significance level: 0.05 ), it was possible to observe a correlation between the results on the audiometry and on the TEOAE (p: 0.002 RE, and p: 0.0006 LE). Therefore, it can be statistically stated that the classification of the auditory thresholds affect the results of the TEOAE (Tables 2 and 3 ). 
Table 2. Correlation between audiometric thresholds and results of transient evoked otoacoustic emissions on right ear

\begin{tabular}{cccc}
\hline Audiometry Classification & Fail & Pass & Overall Total \\
\hline $0-15 \mathrm{~dB}$ & 3 & 4 & 7 \\
$20 \mathrm{~dB}$ and $25 \mathrm{~dB}$ & 4 & 8 & 7 \\
Over 25 dB & 2 & 0 & 2 \\
Overall Total & $\mathbf{9}$ & $\mathbf{1 2}$ & $\mathbf{2 1}$ \\
\hline p-value 0.002484 & & &
\end{tabular}

Legend: $\mathrm{dB}=$ decibel; Statistical Test $=$ Pearson's chi-squared.

Table 3. Correlation between audiometric thresholds and results of transient evoked otoacoustic emissions on left ear

\begin{tabular}{cccc}
\hline Audiometry Classification & Fail & Pass & Overall Total \\
\hline $0-15 \mathrm{~dB}$ & 3 & 4 & 7 \\
$20 \mathrm{~dB}$ and $25 \mathrm{~dB}$ & 4 & 8 & 7 \\
Over $25 \mathrm{~dB}$ & 2 & 0 & 2 \\
Overall Total & $\mathbf{9}$ & $\mathbf{1 2}$ & $\mathbf{2 1}$ \\
\hline
\end{tabular}

p-value 0.002484

Legend: $\mathrm{dB}=$ decibel; Statistical Test $=$ Pearson's chi-squared.

In the analysis of the results of the DPOAE in relation to the pass/fail criteria, it was observed that $81.0 \%(17)$ of the participants passed on both ears (Table 4).
In the DPOAE analysis by specific frequency, a greater percentage of failures in the higher frequencies, of 4 and $5 \mathrm{KHz}$ was observed (Table 5).

Table 4. Occurrence of alterations of distortion-product otoacoustic emissions according to test result and laterality

\begin{tabular}{cccccccc}
\hline \multicolumn{7}{c}{ Prevalence of alterations of the DPOAE } \\
\hline Result & $\mathbf{N}$ & Right Ear & L & Left Ear & & Both Ears \\
\hline Pass & 13 & 61.9 & 17 & $\%$ & $\mathbf{N}$ & $\%$ \\
Fail & 8 & 38.1 & 4 & 19 & 17 & 2 & 9.5 \\
\hline
\end{tabular}

Legend: $\mathrm{N}=$ number; $\%$ = percentage; DPOAE = distortion-product otoacoustic emissions

Table 5. Percentage of pass and fail by frequency in the analysis of distortion-product otoacoustic emissions

\begin{tabular}{ccccccccc}
\hline & $\mathbf{2} \mathbf{~ K H z}$ Pass & $\mathbf{2} \mathbf{~ K H z}$ Fail & $\mathbf{3} \mathbf{~ K H z}$ Pass & $\mathbf{3} \mathbf{~ K H z}$ Fail & $\mathbf{4} \mathbf{~ K H z}$ Pass & $\mathbf{4} \mathbf{~ K H z}$ Fail & $\mathbf{5} \mathbf{~ K H z}$ Pass & $\mathbf{5}$ KHz Fail \\
\hline $\mathrm{RE}$ & $95 \%$ & $5 \%$ & $81 \%$ & $19 \%$ & $67 \%$ & $33 \%$ & $38 \%$ & $62 \%$ \\
$\mathrm{LE}$ & $95 \%$ & $5 \%$ & $81 \%$ & $19 \%$ & $76 \%$ & $24 \%$ & $52 \%$ & $48 \%$ \\
\hline
\end{tabular}

Legend: $\mathrm{RE}=$ right ear; $\mathrm{LE}=$ left ear; $\mathrm{KHz}=$ kilohertz 
The one-way ANOVA test was used for the analysis of dependence between time of noise exposure and the results with the criterion of amplitude and signal-tonoise ratio. The significance value was of $5 \%$, or 0.05 .

In the analysis of the DPOAE results in relation to amplitude averages, it was observed in the frequency of $2 \mathrm{KHz}$ an average of 2.85 for the RE, and 4.67 for the LE. In the frequency of $3 \mathrm{KHz}$, the average was of -1.75 for the RE, and -2.10 for the LE. As for the frequency of $4 \mathrm{KHz}$, the average was of -4.14 for the $\mathrm{RE}$, and -3.67 for the LE. And in the frequency of $5 \mathrm{KHz}$, the average was of -9.00 for the RE, and -5.86 for the LE.

In the comparison between the amplitude averages and the time of the professional's weekly exposure statistical evidence was found in all the frequencies tested, except for $2 \mathrm{KHz}$ on the RE (Table 6). This means that the time the professional is exposed makes the results of the test with amplitude criterion to be altered on both ears.

As for the average of the signal-to-radio parameter, in the frequency of $2 \mathrm{KHz}$, an average of 18.90 was observed for the RE, and 20.48 for the LE. In the frequency of $3 \mathrm{KHz}$ the average was of 17.71 for the RE, and 17.24 for the LE. As for the frequency of $4 \mathrm{KHz}$, the average was of 15.86 for the RE, and 15.86 for the LE. Lastly, in the frequency of $5 \mathrm{KHz}$, the average was of 11.00 for the RE, and 14.90 for the LE.

Table 6. Final results of correlations by amplitude criterion

\begin{tabular}{ccccc}
\hline Frequency & $\mathbf{2 ~ K H z}$ & $\mathbf{3 ~ K H z}$ & $\mathbf{4 ~ K H z}$ & $\mathbf{5 ~ K H z}$ \\
\hline Right Ear & $(p=0.090)$ & $\left(p=0.000005^{\star}\right)$ & $\left(p=0.0000004^{\star}\right)$ & $\left(p=0.000000002^{\star}\right)$ \\
Left ear & $\left(p=0.000009^{\star}\right)$ & $\left(p=0.000009^{\star}\right)$ & $\left(p=0.000006^{\star}\right)$ & $\left(p=0.000006^{\star}\right)$ \\
\hline
\end{tabular}

Legend: $\mathrm{KHz}=$ kilohertz; Statistical test $=$ one-way ANOVA

The analysis revealed that, statistically, the time the professional is exposed does not make the results of the test with signal-to-noise ratio criterion to be altered on both ears. Nonetheless, it was noted that in the frequency of $2 \mathrm{KHz}$ there is a possible correlation that could be better analyzed with the expansion of number of samples (Table 7).

Table 7. Final results of correlations by signal-to-noise criterion

\begin{tabular}{ccccc}
\hline Frequency & $\mathbf{2 K H z}$ & $\mathbf{3 K H z}$ & $\mathbf{4 K H z}$ & $\mathbf{5 K H z}$ \\
\hline Right Ear & $(p=0.092)$ & $(p=0.236)$ & $(p=0.576)$ & $(p=0.577)$ \\
Left ear & $(p=0.029)$ & $(p=0.321)$ & $(p=0.585)$ & $(p=0.585)$ \\
\hline
\end{tabular}

Legend: $\mathrm{KHz}=$ kilohertz; Statistical test $=$ one-way ANOVA

\section{DISCUSSION}

When disc jockeys first appeared as professionals, their role was to not let the music stop, changing records and using a vast repertoire. In Brazil, only in the 1980s this professional stopped being seen as one who played records and took on the role of a DJ, considered as an essential professional in events ${ }^{15}$.

In this research, the results related to hearing complaints demonstrated that $86 \%$ of the participants reported having feeling of ear fullness, and 57\%, tinnitus. These findings serve as a warning, since, according to some authors ${ }^{16}$, tinnitus and feeling of ear fullness after exposure to noise may be the first signs of music-induced hearing loss.

Regarding the symptom most cited by the interviewees - ear fullness - the findings were different from those of other studies conducted with individuals exposed to occupational noise ${ }^{17-20}$, in which tinnitus was the most recurrent complaint. One of the possibilities that may have influenced the symptom of ear fullness in the population of this study is the constant 
use of earphones in at least one of the ears during their professional practice.

Tinnitus, defined as the perception of sound in the head without an external acoustic source, and which has adverse effect on the daily quality of life ${ }^{21}$, was also present in more than half of the sample researched (57\%). A study demonstrated that workers with an average working experience of 6.8 years already have complaint of tinnitus, with this symptom occurring in $70 \%$ of the individuals with normal thresholds exposed to occupational noise. In this study, $67 \%$ of the sample had worked for longer than that average and refer to complaint of tinnitus ${ }^{22}$.

The audiometries conducted pointed to normal auditory thresholds in all frequencies for $90 \%$ of the individuals. Only two subjects presented sensorineural hearing loss (three ears). Nevertheless, there was a portion (38\%) that presented increase in the frequencies of $3 \mathrm{KHz}$ and $6 \mathrm{KHz}$, with worse average found in the frequency of $6 \mathrm{KHz}$, even with auditory thresholds within standards of normality. The same occurred in other studies evaluating hearing in individuals exposed to noise ${ }^{17,23}$. Other studies, though, reported the frequency of $4,000 \mathrm{~Hz}$ as the most impaired $\mathrm{d}^{6,24}$.

It is also emphasized that this increase of thresholds in the frequencies in the range from $3 \mathrm{KHz}$ to $6 \mathrm{KHz}$ may be considered as an important warning sign, once it can indicate a tendency to trigger noise-induced hearing loss throughout time, taking into consideration factors as age group of this sample (20 to 45 years) and noise exposure time, important elements for the development of $\mathrm{NIHL}^{24}$.

A relevant factor which may justify predominantly normal auditory thresholds is the musician's exposure for shorter periods of time, with peak periods and pauses in between them, when the ear can recover, different from workers in factories, who are exposed to continuous noise for almost all day long ${ }^{25}$. According to the same author, music has intense periods followed by periods of silence, and such intermittence is felt by many studies to be the reason why exposure to music may be less dangerous than an equivalent exposure to industrial noise. However, it should be taken into account that the musician will be exposed to intense levels of sound pressure (music) all along their professional career, so that it is essential that they present hearing within standards of normality.

The data presented demonstrate that the population analyzed is at greater risk of developing noise-induced hearing loss. Information furnished by the Comitê
Nacional de Ruído e Conservação Auditiva (National Committee of Noise and Auditory Conservation) $(1994)^{26}$ indicate that NIHL is characterized by the audiogram with hearing loss in the high frequencies, with downward-sloping curve, sensorineural, as well as presenting audiological complaints, among which, tinnitus is one of the most frequent.

The justification for the use of the otoacoustic emissions test is the fact that the very intense noise causes lesions in the structures of the organ of Corti, degenerating first the external hair cells (EHC) in greater amounts and, posteriorly, the internal hair cells $(\mathrm{IHC})^{27}$. Since the OAE exam picks up the functioning of the cochlea through the response of the external cells, the test may reveal the integrity or the alteration of these structures before they indicate irregularities in the pure-tone audiometry exam.

With a sample composed of participants in their majority with normal hearing, a smaller number of alterations was expected; thus, the sensitivity of the TEOAE assessment was a considerable factor.

The percentages found demonstrated that the absence of TEOAE may take place even with supposedly normal auditory thresholds, as it was observed in a research with rock and roll musicians ${ }^{6}$, in which the subjects, despite not presenting hearing loss diagnosed by audiometry, already had cochlear alteration perceived by otoacoustic emissions (OAE). This shows that, in spite of the audiometry not yet revealing hearing loss, these subjects already presented cochlear lesion.

Therefore, it can be suggested that auditory assessment conducted exclusively through pure-tone audiometry may not portray the actual situation of the cochlea functioning of the individuals exposed to noise ${ }^{8}$.

In the comparison between the frequencies of the DPOAE test, it is noted that the frequency of $5,000 \mathrm{~Hz}$ presented diminished amplitude and signal-to-noise ratio - and greater amount of fails - when compared to the other frequencies. Similar datum was found in a study conducted with individuals exposed to drums noise in a college band, which demonstrated, in the frequency of $6,000 \mathrm{~Hz}$ in both ears, a tendency of the control group to present better responses than the exposed group ${ }^{14}$. The amplitude of the otoacoustic emissions represents the amount of external hair cells that are sound. Hence, the reduction of amplitude may predict possible auditory alterations ${ }^{9,27}$. 
It is highlighted that statistical evidence was found in the comparison between the average of amplitudes and the time of the interviewee's weekly exposure. This means that the time the professional is exposed makes the results of the test with amplitude criterion to be altered on both ears. The decrease in amplitude of the transient and distortion product otoacoustic emissions may result from the factory workers' or musicians' exposure to noise ${ }^{14}$.

Considering such facts, as NIHL is irreversible but possible to be prevented, the TEOAE may be of great usefulness in early detection of noise-related cochlear alterations. They may be used as a preventive method in the monitoring of cochlear function in individuals exposed to noise, in this case by the high levels of sound pressure generated by music, detecting alterations before the audiometric results do.

Lastly, it is concluded that hearing loss prevention programs are necessary, as hearing loss in these cases is irreversible, possibly affecting these professionals' performance and quality of life.

\section{CONCLUSION}

The audiological profile of the professionals assessed is characterized by auditory thresholds predominantly within standards of normality, with increase of thresholds in the frequencies of $3 \mathrm{KHz}, 4$ $\mathrm{KHz}$ and $6 \mathrm{KHz}$, which are precisely the ones first affected in the process of $\mathrm{NIHL}$ triggering.

The TEOAEs were absent in a greater number of responses, as compared to the records of the DPOAE, in this sample, even with auditory thresholds within standards of normality.

Music excessively amplified in professional activity may trigger auditory complaints in musicians, such as tinnitus and sensation of ear fullness, identified in this study.

\section{REFERENCES}

1. Macedo EMB, Andrade WTL. Queixas auditivas de Disc Jockeys da cidade de Recife. Rev. CEFAC. 2011;13(3):452-9.

2. Russo ICP, Santos TMM, Busgaib BB, Osterne FJV. Um estudo comparativo sobre os efeitos da exposição à música em músicos de trios elétricos. Rev. bras. otorrinolaringol. 1995;61 (6):477-84.

3. Jorge Junior JJ, Alegre ACM, Greco MC, Angelini MCA, Barros PM. Hábitos e limiares auditivos de jovens em relação à música eletronicamente amplificada em discotecas. Rev. bras. otorrinolaringol. 2001;67(3):297-304.

4. Munhoz GS. Proposta de programa de prevenção de perdas auditivas para músicos. [Dissertação] Bauru (SP): Faculdade de Odontologia de Bauru; 2016.

5. Schink T, Kreutz G, Busch V, Pigeot I, Ahrens W. Incidence and relative risk of hearing disorders in professional musicians. Occup. Environ. Med. 2014;71(7):472-6.

6. Maia JRF, Russo ICP. Estudo da audição de músicos de rock and roll. Pró-Fono R. Atual. Cientif. 2008;20(1):49-54.

7. Fiorini $A C$, Fischer FM. Expostos e não expostos a ruído ocupacional: estudos dos hábitos sonoros, entalhe audiométrico e teste de emissões otoacústicas evocadas por estimulo transiente. Distúrb. Comum. 2004;16(3):371-83.

8. Gattaz G, Wazen SRG. O Registro das Emissões Otoacústicas Evocadas - Produto de Distorção em pacientes com Perda Auditiva Induzida pelo Ruído. Rev. bras. otorrinolaringol. 2001;67(2):213-8.

9. Barros SMS, Frota S, Atherino CCT, Osterne F. A eficiência das emissões otoacústicas transientes e audiometria tonal na detecção de mudanças temporárias nos limiares auditivos após exposição a níveis elevados de pressão sonora. Rev. bras. otorrinolaringol. 2007;73(5):592-8.

10. Lopes Filho O, Carlos R, Redondo MC. Produto de Distorção das Emissões Otoacústicas. Rev. bras. otorrinolaringol. 1995;61(6):485-94.

11. Ottoni AO, Barbosa BA, Boger ME, Garavelli SL. Study of the noise spectrum on high frequency thresholds in workers exposed to noise. Braz. j. otorhinolaryngol. 2012;78(4):108-14.

12. Sistema de Conselhos Federal e Regionais de Fonoaudiologia. Manual de Procedimentos em Audiometria Tonal Limiar, Logoaudiometria e Medidas de Imitância Acústica. 2013:13-27.

13. Gorga M, Norton SJ, Sininger YS, Cone-Wesson B, Folsom RC, Vohr BR et al. Identification of neonatal hearng impairment: distortion product otoacoustic emissions during the perinatal period. Ear hear. 2000;21 (5):400-24.

14. Silva PB, Fiorini AC, Azevedo MF. Otoacoustic emissions in young adults exposed to drums noise of a college band. Rev. CEFAC. 2017;19(5):645-53.

15. Assef C. Todo DJ já sambou: a história do disc-jóquei no Brasil. 2a Ed. São Paulo: Conrad, 2008. 
16. Gonçalves VSB, Lacerda JMV, Brito LKB, Oliveira NCM. Estudo dos hábitos auditivos em estudantes de escola privadas na cidade de João Pessoa. In: XVIII Congresso Brasileiro de Fonoaudiologia. Anais; 2009. Salvador (BA); 21 a 24 de outubro. p. 2417.

17. Luders D, Gonçalves CGO, Lacerda ABM, Schettini SRL, Silva LSG, Albizu EJ et al. Hearing and quality of life in musicians of a symphony orchestra. Audiol., Commun. res. 2016;21:e1688.

18. Silva VG. Avaliação da possível associação de lesão de células ciliadas externas cocleares com a exposição à música amplificada em adolescentes. [Tese] Brasília (DF): Universidade de Brasília; 2017.

19. Gelardi VC, Fiorini AC. Auditory effects and communication disorders in an aerial patrol group. Distúrb. Comun. 2016;8(4):709-17.

20. Lacerda A, Figueiredo G, Massarolo Neto J, Marques JM. Achados audiológicos e queixas relacionadas à audição dos motoristas de ônibus urbano. Rev. Soc. Bras. Fonoaudiol. 2010;15(2):161-6.

21. Oliveira RC, Santos JN, Rabelo ATV, Magalhães MC. The impact of noise exposure on workers in Mobile Support Units. CoDAS. 2015;27(3):215-22.

22. Steinmetz LG, Zeigelboim BS, Lacerda AB, Morata TC, Marques JM. Características do zumbido em trabalhadores expostos a ruído. Rev. bras. otorrinolaringol. 2009;75(1):7-14.

23. Munhoz G, Lopes A. Programa de Prevenção de Perdas Auditivas (PPPA) para músicos. Revista Portuguesa de Saúde Ocupacional. 2016;1:72-81. DOI:10.31252/RPSO.22.06.2016

24. Lopes AC, Nelli MP, Lauris JRP, Amorim RB, Melo ADP. Condições de saúde auditiva no trabalho: investigação dos efeitos auditivos em trabalhadores expostos ao ruído ocupacional. Arq. int. otorrionlaringol. 2009;13(1):49-54.

25. Chasin M. Musicians and the prevention of hearing loss. San Diego: Singular Publishing Group, 1996.

26. Comitê Nacional de Ruído e Conservação Auditiva. Perda auditiva induzida pelo ruído relacionado ao trabalho. Acta AWHO. 1994;13:126-7.

27. Coelho MS, Ferraz JRS, Almeida EOC, Almeida Filho N. As emissões otoacústicas no diagnóstico diferencial das perdas auditivas induzidas por ruído. Rev. CEFAC. 2010;12(6):1050-8. 